\title{
Vital Fungal Resistance Gene of Tomato: Identified Genes in the Wild Source of Tomato
}

\author{
Mulusew Kassa Bitew \\ Department of Plant Science, College of Agriculture and Natural Resources, Debre Markos University, \\ P.O. Box: 269, Debre Markos, Ethiopia
}

\begin{abstract}
Tomato (Solanum lycopersicum L.) is the second most important and consumable vegetable crop after potato in the world. Though tomato is very important consumable vegetable and a model plant for genetic studies, its quality, and yield have been immensely declined by different biotic and abiotic factors and among the biotic factors fungal disease are the most devastating, could cause $100 \%$ yield loss in sever condition. Major fungal diseases of tomato posing a threat in tomato production are late blight caused by Phytophthora infestans, early blight caused by Alternaria solanii, septoria leaf spot caused by Septoria lycopersici, fusarium wilt Fusarium oxysporium $f_{s p}$. Oxysporium and verticilium wilt caused by Verticilium dahlea. Other fungal diseases of tomato include powdery mildew caused by Oidium lycopersicum and leaf mold caused by Cladosporium fulvum. To overcome this using resistance gene from the wild source is fundamental and the aim of this review was to appraise and discuss the major identified fungal resistance genes of tomato. There are 16 wild relatives of the cultivated tomato which are reach id different disease resistance genes and currently, among approximately 35,000 encoding genes of tomato twenty two genes have been reported that they are fungal resistance genes which are found in almost all chromosomes except chromosome two and five with available molecular markers. Using this as an opportunity and use different conventional and molecular techniques for gene pyramiding is indispensable.
\end{abstract}

Keywords: Solanum lycopersicum, wild source, major fungal diseases, identified resistance genes, chromosome of the gene, pyramiding

DOI: $10.7176 / \mathrm{JBAH} / 9-17-05$

Publication date:September $30^{\text {th }} 2019$

\section{Introduction}

Tomato (Solanum lycopersicum L.) is the second most important vegetable crop after potato in the world. It is estimated that 4.6 million hectare of tomato are grown worldwide annually producing more than 126 million metric ton (http://faostat.fao.org). It is also second most consumed vegetable next to Potato in the world which is used as salad, paste, whole peeled tomatoes, diced products, and various forms of juice, sauces, and soups. It is a significant source of vitamin $\mathrm{A}$ and $\mathrm{C}$ as well red tomato is the major component of lycopene which has an antioxidant property to protect human against cancer and heart disease (Elcio P. et.al., 2007). In addition it is being used as a model plant species for genetic studies of qualitative and quantitative traits related to fruit quality, biotic and abiotic factors. Because of its economical contribution to agricultural industry there is an abundant interest to use genomic tools in improving the genomic composition of tomato to meet the interest of the demand in quality, disease resistance as well as to increase yield per acre (Panthee \& Chen, 2009). The problem of plant diseases is a worldwide issue also related to food security (Park, 2017). According to the World Food Program (WFP), about 795 million people in the world do not have access to get a proper food (WFP, 2016 and Park, 2017). Transboundary plant pests and diseases affect food crops, causing significant losses to farmers and threatening food security (http://faostat.fao.org). Nowadays, no matter boundaries, media or technology, the effect of diseases in plants are becoming a challenging approach, and deserves to be treating with special attention (Park, 2017. In spite of the fact that results have been obtained via conventional breeding and selection in decades, there are still a large number of fungal diseases that make tomato production challenging in various parts of the world. This is because of limited wild resistance cultivars and the ability of the pathogen becoming virulent against the resistance gene of the cultivars (Richard et al 1998). This trigger the breeders towards another mechanisms and advanced tools like functional and structural genomics to overcome tomato yield problem. As a result, this review initiates to appraise and discuss identified genes of tomato resistance to fungi diseases. Major fungal diseases of tomato posing a threat in tomato production are late blight caused by Phytophthora infestans, early blight caused by Alternaria solanii, septoria leaf spot caused by Septoria lycopersici, fusarium wilt Fusarium oxysporium fsp. oxysporium and verticilium wilt caused by Verticilium dahlea. Other fungal diseases of tomato include powdery mildew caused by Oidium lycopersicum and leaf mold caused by Cladosporium fulvum (Panthee, and Chen, 2009). Fusarium and verticilium wilt are vascular diseases, while late blight, early blight $\&$ septoria leaf are foliar diseases which have been causing significant crop losses annually and more important one worldwide. Depending on weather condition determination of the disease, crop loss may range from mild to the complete loss. 


\section{Fungi tomato disease}

According to the environmental condition and the type of the cultivar the severity of the disease will highly differ. But for this review the emphasis is given to the most important fungal diseases and tomato genes responsible for those diseases. But this does not mean the genes which are resistance to fungi will not work on other biotic and abiotic factors. Based on the principle of gene to gene interaction; plants that are producing a specific $\mathrm{R}$ gene product are resistant towards the pathogen that produces an Avr gene product.

\subsection{Important Foliar Fungal Diseases}

\section{A. Late blight (LB)}

Late blight is caused by the notorious oomycete (a distinct phylogenetic lineage of fungus-like eukaryotic microorganisms, also known as (water molds) Phytophthora infestans one of the most destructive and contagious diseases for field-grown tomatoes (Margulis and Chapman, 2009). This pathogen can destroy the potato crop within a few days because of its elevated virulence as an $\mathrm{R}$ gene destroyer, capability to rapidly adapt to resistant plants and its high evolutionary potential (Vleeshouwers et al., 2011). This happens to tomato crop and total loss is not uncommon, especially if management practices are not used, because the pathogen directly affects fruit and kills plants. If the pathogen favoured by cool temperatures and humid, rainy or foggy it can spread in a very short period of time since a single lesion can produce as many as 300,000 sporangia per day (Foolad et al., 2008). During initial stages of infection it is very difficult to detect $P$. infestans in the field, and because of this and its very short life cycle, it is hard and late to protect the crop through fungicide application when the disease become detectable (Tyler et al., 2006 \& Panthee \& Chen, 2009). Though different chemical and agronomical practices have been implemented, it couldn't be effective as finding the resistance gene and breeding to the cultivated one. Late blight resistance in wild tomato species reported, especially in S. pimpinellifolium and S. habrochaites (Wang et al., 2016).

\section{B. Early blight (EB)}

Early blight (EB) is one of the appalling diseases of tomato, which causes an estimated annual economic yield losses of 79\% (Foolad, 2007, Foolad et al, 2008, Panthee \& Chen, 2009 and Adhikari, Oh, \& Panthee, 2017).

Early blight can be caused by two different closely related fungi species Alternaria linariae (which contains two formaspecialiea; Alternaria tomatophila and Alternaria solani) and A. alternate. Alternaria tomatophila is more virulent on tomato than $A$. solani and if $A$. tomatophila is absent, $A$. solani will cause early blight on tomato. In addition to tomato early blight can also infect potato, eggplant and several Solanaceous weeds including black nightshade (Solanum ptycanthum), and hairy nightshade (Solanum physalifolium).

Alternaria are known only to reproduce asexually, but a highly-virulent isolate has the potential to overcome existing resistance genes, especially in areas of heavy dew, frequent rainfall, and high relative humidity (RH); it can also be important in semi-arid areas when nightly dew is frequent (Frey and Horner, 1957; Dudley and Moll, 1969; Falconer, 1989; Agrios, 2005 \& Panthee \& Chen, 2009). This disease has 3-phase of developmental pathogenicity; produce collar rot, leaf blight (early blight) and fruit rot (Foolad, 2007). Collar rot has serious implications for tomato growers both as a disease and as a source of inoculum for an EB epidemic. The leaf blight phase, commonly denoted to as early blight, is characterized by the formation of dark-colored spots that are necrotic in the center and result in a concentric ring pattern. As lesions expand and become more numerous, leaves are blighted and plants are gradually defoliated. The most important phase of the disease is defoliation, which reduces yield and fruit quality and contributes to significant crop loss. Almost all member species of the Solanaceae can serve as alternate host for overwintering of the pathogen. No genetic source of EB resistance is known within the cultivated species of tomato (Foolad, 2007). However, resistant accessions have been identified within related wild species of tomato, in particular the green-fruited species Solanum habrochaites, S. hirsutum S. arcanum and $S$. pimpinellifolium with moderate resistance have been developed through conventional breeding methods, but none of them could be used in EB resistance breeding due to low individual QTL effects (Foolad, 2007 and Adhikari, Oh, \& Panthee, 2017).

\section{Septoria leaf spot (SLS)}

Septoria leaf spot (SLS) (caused by Septoria lycopersici Speg) is yet another destructive foliar disease favoured by extended periods wet and humid weather conditions with symptom of circular lesions first appear on the lower leaves, thereafter appearing on stem, petioles and spreads upward to calyx which then can cause complete defoliation leading to a significant crop loss(Joshi et al., 2015). Although fungicides are effective to control this disease, breeding for resistance is preferred by tomato growers due to the costs involved in the management of the disease and their associated environmental hazards. Useful levels of resistance have also been found in S. pennelli, S. pimpinellifolium, $S$. chilense, and $S$. lycopersicum var. cerasiforme and it has been reported that resistance to SLS is controlled by a single dominant gene (Joshi et al., 2015).

\section{D. powdery mildew (PW)}

It is caused by fungi called Oidium neolycopersici though the origin of this disease is still unclear it was first reported in the Netherlands in 1986 and since then has spread rapidly world-wide (Paternotte 1988). Apart from a 
few modern resistant cultivars, most of the tomato cultivars are susceptible to $O$. neolycopersici. Promising sources of resistance to $O$. neolycopersici are available in different Solanum species like $S$. hirsutum and $S$. esculentum var cerasiforme.

Another species of tomato powdery mildew, Leveillula taurica (Lev.) Arm., has been reported first in USA to occur in subtropical regions and may cause losses of up to $40 \%$ of tomato crop yields (Jones and Thomson, 1987) . The mycelium of L. taurica grows into the leaf and is visible on the lower side of the leaf. It is different from $O$. neolycopersici that grows mainly on the upper epidermis and usually does not penetrate the leaf (Lindhout et al. 1994a).

\subsection{Vital Vascular Fungal Diseases}

\section{A. Fusarium wilt (FW)}

Fusarium wilt caused by Fusarium oxysporum f. sp. lycopersici is a destructive disease of tomato crops worldwide and it may causes up to $80 \%$ yield reduction (Akbar et al., 2016)

There are two distinct forms of the pathogen Fusarium wilt, F. oxysporum f. sp. lycopersici W. C. Snyder \& H. N. Hans which causes vascular wilt, and F. oxysporum f. sp. radicis-lycopersici W. R. Jarvis \& Shoemaker which is a necrotrophic pathogen, causal agent of tomato crown and root rot (FORL), which results in severe losses in the greenhouse, field crops and hydroponic cultures (McGovern RJ, 2015). Although various methods have been employed to control this pathogen, the use of resistant cultivars is the most acceptable and economic system of control (Szczechura W. et al, 2013). Both of these pathogens are soil borne and occur throughout most tomato growing areas (Agrios, G.N. 2005 \& Panthee \& Chen, 2009). Infected leaves start drooping, curve downwards and turn yellow. Disease symptoms are apparent during flowering and fruiting stages, and leaflets on one side of the plants typically show more severe symptoms than leaves on the other side because of the specific vascular tissue affected by the pathogen. Subsequently, plants start wilting during hot days and eventually die (Jones et al, 1991 \& Panthee \& Chen, 2009). Fusarium oxysporum f. sp. lycopersici have three races, race 1(Avr1), 2 (Avr2) and 3 (Avr3), of which race 3 is the most devastating.

\section{B. Verticilium wilt (VW)}

Verticilium wilt (VW) caused by Verticilium dahliae is also a soil borne Ascomycete and like FW causes significant losses in tomato. $V$. dahliae has a wide host range and is distributed throughout the world. The fungus overwinters in plant debris and alternate hosts. Relatively cool temperatures, high humidity and high soil moisture are conducive to the spread of this disease (Agrios, $2005 \&$ Panthee \& Chen 2009). Disease symptoms appear on the lower leaves as yellow blotches, wilting and eventually dropping off. There are two races of this fungus that are active in tomato, $\mathrm{Ve}-1$ and $\mathrm{Ve}-2$.

\section{Wild genetic Resources of Tomato}

Tomato, the genus Solanum; formerly was nested in the genus Lycopersicon (and the cultivated Solanum lycopersicum L., formerly Lycopersicon esculentum Miller) contains seventeen wild species (including the cultivated $S$. lycopersicum) has a diploid genome size of $950 \mathrm{Mb}$ with 12 chromosome pairs encoding approximately 35,000 genes and most intensively investigated Solanaceous species for genetic studies (Bai, 2004; Foolad, 2007; Barone et al., 2008 and Bitew,2018). All those species; S. cheesmaniae, S. galapagense, S. chilense, S. chmielewskii, S. habrochaites, S. neorickii, S. pennellii, S. arcanum, S. corneliomulleri, S. huaylasense, S. peruvianum, S. pimpinellifolium, S. juglandifolium, S. lycopersicoides, S. ochranthum, S. sitiens and the cultivated S. lycopersicum exhibits great difference in morphological characters such as matting system, for biotic and abiotic resistance, and other agronomic traits important for breeding Bitew, (2018). Though hybridization barriers to make crossign was told by Bai, (2004) between the two Solanum complexes; the "esculentum complex which consists of fourteen species, and the "peruvianum complex which is comprised of two extremely diverse species, S. chilense and S. peruvianum" (Figure 1), gene transfer is possible using Molecular and various embryo rescue techniques between the wild species and to the cultivated tomato (Rick, 1982; Rick and Yoder, 1988 and Foolad, 2007).

Hence, the cultivated tomato has a narrow genetic diversity that resulted from its intense selection and inbreeding during evolution and domestication (Zhang et al., 2002 and Adhikari, Oh, \& Panthee, 2017); thus, these species are more prone to disease epidemics. Because of many traits of economic importance like almost all the major disease resistances including insects like Tuta basoluta (Bitew, 2018) originate from wild Lycopersicon species as well for abiotic factors tolerance genes than cultivated tomato species. Therefore, the hindrance caused by several diseases can be tackled through the development of resistant cultivars by plant breeding approaches utilizing resistance in the wild species. To identify the resistance gene knowing the wild species of the domesticated crop have crucial role for the breeders. As a result, there is a great diversification to improve cultivated tomato for yield and to combat pathogens that minimizes the quality and quantity of desired tomato yield. Though there were this much informative and sequenced genome data available from the cultivated tomato and there are still huge gaps and possibilities to incorporate resistance gene and pyramiding from those wild relatives. 


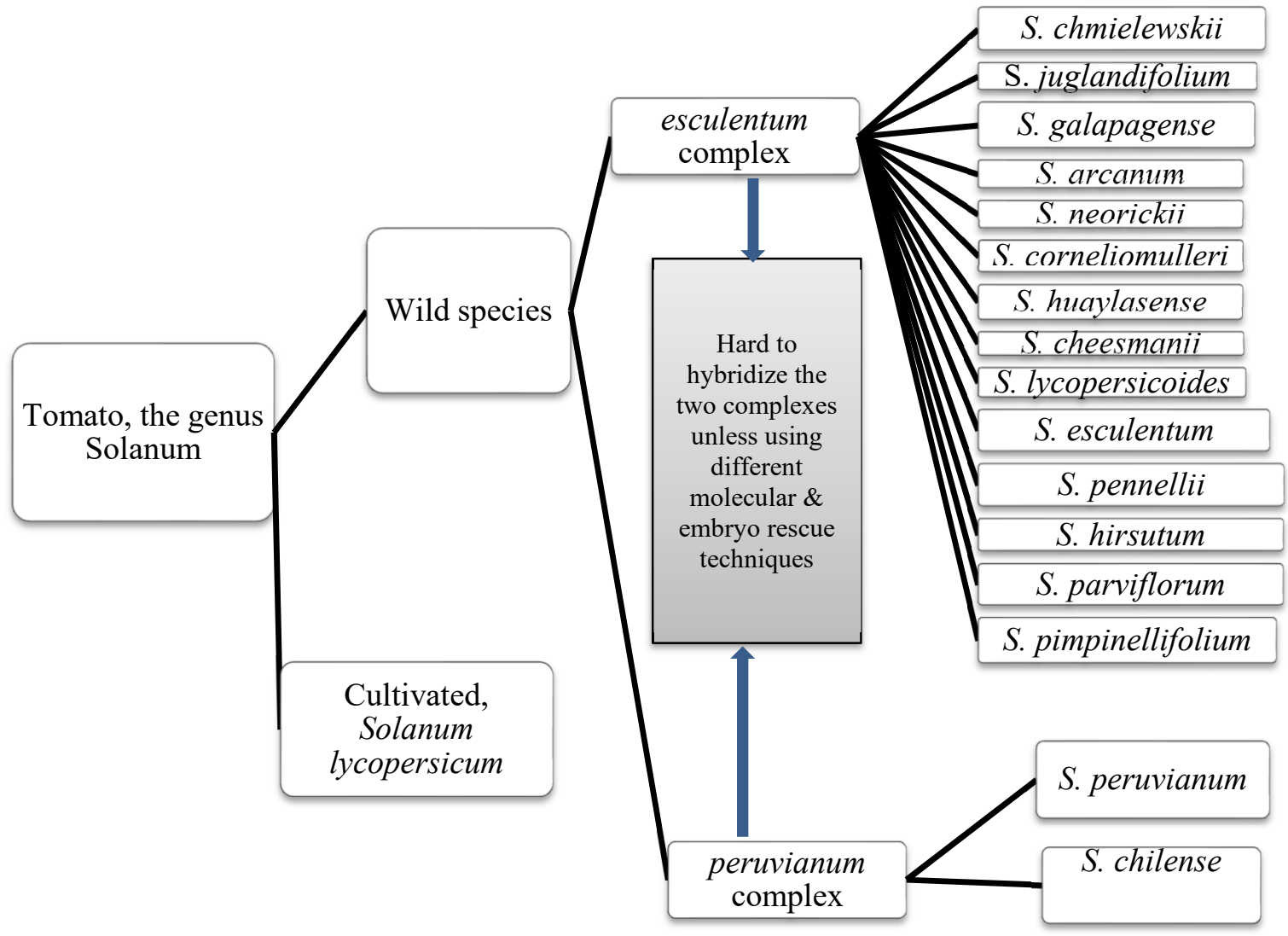

Figure 3: Wild genetic resources of the cultivated tomato, S. lycopersicum

The prodigious thing is that there is an ample Molecular and conventional technique to introgress fungal resistance gene of wild species to the cultivated tomato.

\section{Major Fungal Resistance genes of tomato}

Based on the concept of gene to gene model that for every fungal avirulence gene (Avr) there is a corresponding tomato resistance gene that mediates recognition of the fungal pathogen by the host in which the defence responses are activated culminating in a hypersensitive response (a type of programmed cell death) that limits further growth of this biotrophic pathogen.

For late blight disease there are five resistance genes in tomato, $\mathrm{Ph}-1, \mathrm{Ph}-2, \mathrm{Ph}-3, \mathrm{Ph}-4 \& \mathrm{Ph}-5$ (Table 1) which is mainly derived from Solanum pimpinellifolium, the wild relative of tomato. $P h-5$ is the newly resistance gen which confers resistance to several pathogen isolates including those overcoming the previous resistance genes ((Foolad et al, 2008; Truong et.al 2013 \& Akbar et.al 2016).

Four resistance gene of tomato against Fusarium wilt; for the $F$. oxysporum $\mathrm{f}$. sp. lycopersici four genes, i.e., $I-1, I-2, I-3 \&$ I-7, and one gene for the F. oxysporum f. sp. radicis-lycopersici; $\mathrm{Fr} I$ have been developed and other fungal disease resistance genes also shown (Table 1). The presence of two or more gene for a given pathogen indicates that the pathogen suppressed the previous gene and then tomato developed new gene for resistance and it continues in such away as gene-to-gene concept.

The most important thing is designing techniques and pyramiding those genes to one single cultivar for the sec of getting multiple disease resistance gene of tomato against fungal diseases. Hence gene pyramiding is so critical technique to attain durable resistance against biotic and abiotic stresses in crops, and supply the great demand of food to steadily increasing population and alleviate the erroneously changing climatic condition.

So there are options to select parental lines form those wild tomato sources and make cross with an integration of marker assisted selection throughout each generation. Hence these helps for the confirmation of inherited traits to the next generation and amend the breeding techniques. 
Table 4: Major fungal resistance gene of tomato

\begin{tabular}{|c|c|c|c|c|c|c|}
\hline Resistance Genes & Fungi strain/species & $\begin{array}{l}\text { Common } \\
\text { name of the } \\
\text { disease }\end{array}$ & $\begin{array}{l}\text { location of the } \\
\text { gene on } \\
\text { chromosom }\end{array}$ & Resistance Source & $\begin{array}{l}\text { Available } \\
\text { Molecular } \\
\text { Markers }\end{array}$ & References \\
\hline Fr1 & $\begin{array}{l}\text { Fusarium oxysporium } \\
\text { f.sp. radicus- } \\
\text { lycopersici }\end{array}$ & & 9 & & CAPS & \\
\hline$I-1, I-2, I-3 \& I-7$ & $\begin{array}{l}\text { Fusarium oxysporium } \\
\quad \text { f.sp. lycopersici }\end{array}$ & $\begin{array}{l}\text { Fusarium } \\
\text { Wilt }\end{array}$ & $7,11,7 \& 8$ & S. pimpinellifolium \& S. pennellii & ssR & $\begin{array}{l}\text { An-Maree C. et.aL,(2015) and } \\
\text { Gonzalez-Cendales, } \\
\text { Catanzariti, Baker, Megrath, } \\
\text { \& Jones, (2016) }\end{array}$ \\
\hline $\begin{array}{l}P h-1 . p h-2, p h-3 \\
P h-5\end{array}$ & Phytophtera infestan & Late blight & $7,10,9,1$ & Solanum pimpinellifolium & ssR & $\begin{array}{c}\text { Majid R et al.,(2012), Truong } \\
\text { et.al,,(2013) \& Akbar et.al, } \\
\text { (2016) }\end{array}$ \\
\hline$V e 1 \& V e 2$ & Verticulium dahlia & $\begin{array}{l}\text { Verticilium } \\
\text { wilt }\end{array}$ & 9 & Solanum lycopersicum, Craigella cultivar & SCAR & $\begin{array}{l}\text { Kawchuk et al, } 2001 \text { \& } \\
\text { Acciarri et al., (2007) }\end{array}$ \\
\hline $\begin{array}{l}L v, O L-1, o l-2 \text { and } \\
\quad \text { Ol-3 }\end{array}$ & Oidium neolycopersici & $\begin{array}{l}\text { Powdery } \\
\text { Mildew }\end{array}$ & $12,6,4 \& 6$ & $\begin{array}{l}\text { S. chilense, S. hirsutum and } S . \text { esculentum } \\
\text { var cerasiforme. }\end{array}$ & RFLP & $\begin{array}{l}\text { Huang et al., 2000c \& Van } \\
\text { der Beek et al. } 1994\end{array}$ \\
\hline $\begin{array}{l}C f-1, C f-2, C f-4 \\
C f-5, C f-9\end{array}$ & Cladosporium fulvum & $\begin{array}{l}\text { Tomato leaf } \\
\text { mould }\end{array}$ & $1,6,1,6,1$ & $\begin{array}{l}\text { S. pimpinellifolium, } S \text {. hirsutum, } L \text {. } \\
\text { esculentum var. cerasiforme }\end{array}$ & RFLP & $\begin{array}{l}\text { Kerr \& Bailey } 1964 \text { and } \\
\text { Dickinson et al. } 1993\end{array}$ \\
\hline$P y-1$ & $\begin{array}{l}\text { Phyrenochaeta } \\
\text { Lycopersici }\end{array}$ & $\begin{array}{l}\text { Corky root } \\
\text { rot }\end{array}$ & 3 & S. peruvianum \& S. hirsutum & CAPS & $\begin{array}{l}\text { Bubici, Carluccio, \& Cillo, } \\
\text { (2016) }\end{array}$ \\
\hline Asc & $\begin{array}{l}\text { Alternaria alternata } \\
\text { f.sp. lycopersici }\end{array}$ & $\begin{array}{c}\text { Alternaria } \\
\text { stem canker }\end{array}$ & 3 & S. esculentum & RFLP & Brandwagt et al, 2000 \\
\hline
\end{tabular}

CAPS = Cleaved Amplified Polmorphic Sequence; SCAR = Sequence Characterized Amplified Region; ssR = Simple Sequence Repeats; RFLP = Restricted Fragment Length Polymorphism

\section{Conclusion and Recommendation}

Though the importance of tomato ( $S$, lycopersicum) sympathetic in all of our dishes and day to day consumption, it have been reported that fungal diseases of tomato are causing critical yield loss estimates almost $100 \%$ in sever condition. So to overcome this problem the cost effective, efficient and environmental friendly approach is developing new resistance variety that could be durable for long period and for multiple diseases. In modern and basic plant science, $S$, lycopersicum is the second next to Arabidopsis thaliana as it have been excellent model plants because it has a relatively small genome and is suitable for genome manipulation. Using this as an opportunity and use different conventional and molecular techniques for gene pyramiding is indispensable. Though the success of gene pyramiding depends on a lot of factors such as distance between the closest markers and the target gene, number of target genes to be transferred, genetic base of the trait, number of individuals that can be analysed, genetic background in which the target gene has to be transferred, type of molecular marker used and available technical facilities, it stacks multiple genes leading to the simultaneous expression of more than one gene in a variety to develop durable resistance expression and improve the efficiency of plant breeding leading to the development of genetic stocks and precise development of broad spectrum resistance capabilities. There are 16 wild relatives of tomato which are reaching in its biotic and abiotic resistance like $S$. pimpinellifolium, $S$. pennellii, $S$. chilense, $S$. hirsutum and others, which can be used as parental line to introgress their gene towards farmer preferred cultivar of tomato. On those wild relative sources of tomato around 22 genes are available for fungal resistance along 10 pair of chromosomes. So this is interesting to incorporate in the breeding scheme with the help of molecular techniques. Especially in the developing world there is deepen need of using molecular techniques relative to the conventional breeding system, hence and unless there would a great far away behind to supply food to the increasing population and its demand, and the effect is massive by biotic and abiotic factors.

\section{References}

Acciarri, N., Rotino, G. L., Tamietti, G., Valentino, D., Voltattorni, S., \& Sabatini, E. (2007). Molecular markers for Ve1 and Ve2 Verticillium resistance genes from Italian tomato germplasm. Plant Breeding, 126(6), 617621. https://doi.org/10.1111/j.1439-0523.2007.01398.x

Adhikari, P., Oh, Y., \& Panthee, D. R. (2017). Current status of early blight resistance in tomato: An update. International Journal of Molecular Sciences, 18(10). https://doi.org/10.3390/ijms18(10),2019.

Agrios, G.N.; Plant Pathology, 5th ed. 2005, New York Elsevier.

Akbar, K., Abbasi, F. M., Sajid, M., Ahmad, M., Khan, Z. U., \& Ali, H. (2016). Marker-assisted selection and pyramiding of $\mathrm{I} 1$ and $\mathrm{Ph} 3$ genes for multiple disease resistance in tomato through PCR analysis. International Journal of Biosciences (IJB), 9(3), 108-113. https://doi.org/10.12692/ijb/9.3.108-113.

Bai, Y. (2004). The genetics and mechanisms of resistance to tomato powdery mildew ( Oidium neolycopersici ) in Lycopersicon species. https://doi.org/90-8504-100-7 
Barone, A., Chiusano, M. L., Ercolano, M. R., Giuliano, G., Grandillo, S., \& Frusciante, L. (2008). Structural and functional genomics of tomato. International Journal of Plant Genomics, 2008. https://doi.org/10.1155/2008/820274.

Bitew, M. K. (2018). Significant role of wild Genotypes of tomato trichomes for Tuta absoluta resistance, 2(1), 112.

Brandwagt, B. F., Mesbah, L. A., Takken, F. L. W., Laurent, P. L., Kneppers, T. J. A., Hille, J., \& Nijkamp, H. J. J. (2000). <3 Brandwagt, 2000.pdf>, (3).

Bubici, G., Carluccio, A. V., \& Cillo, F. (2016). Characterization of the tomato py-1 locus conferring recessive resistance against Pyrenochaeta lycopersici, (September).

Dickinson, M. J., Jones, D. A. \& Jones, J. D. G. 1993 Close linkage between the Cf-2/Cf-5 and Mi resistance loci in tomato. Molec. Plant ${ }^{\wedge}$ Microbe Interact. 6, 341-347.

Elcio P. Guimaraes, J. R., Beate D. Scherf, Andrea Sonnina and James D. Dargie (2007). "Molecular Marker Assisted Selection for Resistance to Pathogen in Tomato." Food and Agriculture Organization of the United Nations: 152-159.

Foolad, M. R. (2007). "Genome Mapping and Molecular Breeding of Tomato." Volume 2007, Article ID 64358, 52 pages doi: $10.1155 / 2007 / 64358$

Foolad, M.R.; Merk, H.L.; Ashrafi, H.( 2008) Genetics, genomics and breeding of late blight and early blight resistance in tomato. Crit. Rev. Plant Sci., 2008, 27, 75-107.

Gonzalez-Cendales, Y., Catanzariti, A. M., Baker, B., Mcgrath, D. J., \& Jones, D. A. (2016). Identification of I-7 expands the repertoire of genes for resistance to Fusarium wilt in tomato to three resistance gene classes. Molecular Plant Pathology, 17(3), 448-463. https://doi.org/10.1111/mpp.12294.

Huang C.C., Van de Putte P.M., Haanstra-van der Meer J.G., Meijer-Dekens F. and Lindhout P. 2000c. Characterization and mapping of resistance to Oidium lycopersicum in two Lycopersicon hirsutum accessions: Evidence for close linkage of two $\mathrm{Ol}$-genes on chromosome 6. Heredity 85: 511-520.

Joshi, B. K., Louws, F. J., Yenco, G. C., Sosinski, B. R., Arellano, C., \& Panthee, D. R. (2015). Molecular Markers for Septoria Leaf Spot (Septoria lycopersicii Speg.) Resistance in Tomato (Solanum lycopersicum L.). Nepal Journal of Biotechnology, 3(1), 40-47. https://doi.org/10.3126/njb.v3i1.14230.

Jones, J.B.; Jones, J.P.; Stall, R.E.; Zitter, T.A. Compendium of tomato diseases. Compendium of Tomato Diseases. 1991, St. Paul, Minnesota, USA., The American Phytopathological Society. VIII+73P 1991.

Kawchuk, L.M., Hachey, J., Lynch, D.R., Kulcsar, F., van Rooijen, G., Waterer, D.R., Robertson, A., Kokko, E., Byers, R., Howard, R.J., Fisher, R. and Prfer, D. 2001. Tomato Ve disease resistance genes encode cell surface-like receptors. Proc. Natl. Acad. Sci. USA 98:6511-6515.

Kerr, E. A. \& Bailey, D. L. 1964 Resistance to Cladosporium fulvum Cke obtained from wild species of tomato. Can. J. Bot.42, 1541-1553.

Lindhout P., Van der Beek H. and Pet G. 1994. Wild Lycopersicon species as sources for resistance to powdery mildew (Oidium lycopersicum): Mapping of resistance gene Ol-1 on chromosome 6 of Lycopersicon hirsutum. Acta Hortic. 376: 387-394.

Majid R. Foolad, Dilip R. Panthee. (2012) Marker-Assisted Selection in Tomato Breeding. Critical Reviews in Plant Sciences 31:2, pages 93-123.

Margulis L., Chapman M. (2009). Kingdoms and Domains. an illustrated guide to the phyla of life on earth. W.H. Freeman and Co., New York, N.Y.

McGovern RJ. Management of tomato diseases caused by Fusarium oxysporum. Crop Prot. 2015;73:78-92.

Panthee, D., \& Chen, F. (2009). Genomics of Fungal Disease Resistance in Tomato. Current Genomics, 11(1), 30-39. https://doi.org/10.2174/138920210790217927.

Park, D. S. (2017). Characteristics of Tomato Plant Diseases, (October 2016).

Paternotte S.J. 1988. Echte meeldauw in tomaat geen echte bedreiging. Groenten en Fruit 43: 30-31.

Richard lauge, m. h. a. j. j., jair p. w. haanstra, paul h. goodwin, pim lindhout, and A. P. J. G. M. D. WIT (1998). "Successful search for a resistance gene in tomato targeted against a virulence factor of a fungal pathogen." Vol. 95, pp. 9014-9018.

Rick C.M. 1982. Genetic relationships between self-incompatibility and flora traits in the tomato species. Biol. Zentralbl. 101: 185-198.

Rick C.M. and Yoder J. I., 1988. Classical and molecular genetics of tomato highlights and perspectives. Annu.

Rev. of Genetics, 22: 281-300.

Szczechura W, Staniaszek M, Habdas H. Fusarium oxysporum F. Sp. radicis-lycopersici - the cause of fusarium crown and root rot in tomato cultivation. J Plant Prot Res. 2013;53:2-6.

Truong HTH, Tran HN, Choi HS, Park PH, Lee HE. 2013. Development of a co-dominant SCAR marker linked to the Ph-3 gene for Phytophthora infestans resistance in tomato (Solanum lycopersicum). European Journal of Plant Pathology 136(2), 237-245.http://dx.doi.org/10.1007/s10658-012-0157-4.

Tyler, B.M.; Tripathy, S.; Zhang, X.M.; Dehal, P.; Jiang, R.H.Y.; Aerts, A.; Arredondo, F.D.; Baxter, L.; 
Bensasson, D.; Beynon, J.L.; Chapman, J.; Damasceno, C.M.B.; Dorrance, A.E.; Dou, D.L.; Dickerman, A.W.; Dubchak, I.L.; Garbelotto, M.; Gijzen, M.; Gordon, S.G.; Govers, F.; Grunwald, N.J.; Huang, W.; Ivors, K.L.; Jones, R.W.; Kamoun, S.; Krampis, K.; Lamour, K.H.; Lee, M.K.; McDonald, W.H.; Medina, M.; Meijer, H.J.G.; Nordberg, E.K.; Maclean, D.J.; Ospina-Giraldo, M.D.; Morris, P.F.; Phuntumart, V.; Putnam, N.H.; Rash, S.; Rose, J.K.C.; Sakihama, Y.; Salamov, A.A.; Savidor, A.; Scheuring, C.F.; Smith, B.M.; Sobral, B.W.S.; Terry, A.; TortoAlalibo, T.A.; Win, J.; Xu, Z.Y.; Zhang, H.B.; Grigoriev, I.V.; Rokhsar, D.S.; Boore, J.L. Phytophthora genome sequences uncover evolutionary origins and mechanisms of pathogenesis. Science, 2006, 313, 1261-1266.

Van der Beek J.G., Pet G., Lindhout P. 1994. Resistance to powdery mildew (Oidium lycopersicum) in Lycopersicon hirsutum is controlled by an incompletely dominant gene $\mathrm{Ol}-1$ on chromosome 6 . Theor. Appl. Genet. 89: 467-473.

Vleeshouwers V.G., Raffaele S., Vossen J.H., Champouret N., Oliva R., Segretin M.E., Rietman H., Cano L.M., Lokossou A., Kessel G., Pel M.A., Kamoun S. (2011). Understanding and exploiting late blight resistance in the age of effectors. Annual review of phytopathology, 49, 507-531.

Wang, Y. Y., Chen, C. H., Hoffmann, A., Hsu, Y. C., Lu, S. F., Wang, J. F., \& Hanson, P. (2016). Evaluation of the Ph-3 gene-specific marker developed for marker-assisted selection of late blight-resistant tomato. Plant Breeding, 135(5), 636-642. https://doi.org/10.1111/pbr.12395.

W.B. Jones, S.V. ThomsonSource of inoculum, yield, and quality of tomato as affected by Leveillula taurica Plant Dis., 71 (1987), pp. 266-268.

W. F. Programme, "World Food Programme - Hunger Statistics," United Nations, 2016. [Online]. Available: https://www.wfp.org/hunger/stats.

Zhang, L.P.; Khan, A.; Nino-Liu, D.; Foolad, M.R. A molecular linkage map of tomato displaying chromosomal locations of resistance gene analogs based on a Lycopersicon esculentum Lycopersicon hirsutum cross. Genome 2002, 45, 133-146. 